\title{
Effect of Bicarbonate on the Growth of Actinobacillus actinomycetemcomitans in Anaerobic Fructose-limited Chemostat Culture
}

\author{
By HIROYUKI OHTA, * KAZUHIRO FUKUI AND KEIJIRO KATO \\ Department of Microbiology, Okayama University Dental School, Shikata-cho, \\ Okayama 700, Japan
}

(Received 23 June 1989; revised 22 August 1989; accepted 18 September 1989)

\begin{abstract}
The effect of bicarbonate on the growth and product formation by a periodontopathic bacterium, Actinobacillus actinomycetemcomitans, was examined in an anaerobic chemostat culture with fructose as the limiting nutrient. The chemostat cultures were run at dilution rates between 0.04 and $0.25 \mathrm{~h}^{-1}$ and the maximum growth yield $\left(Y_{\text {fructose }}^{\max }\right)$ was estimated to be 40.3 and $61.7 \mathrm{~g}$ dry wt (mol fructose) $)^{-1}$ in the absence and presence of bicarbonate, respectively. The major fermentation products in the absence of bicarbonate were formate, acetate, ethanol and succinate, with small amounts of lactate. The addition of bicarbonate to the medium resulted in a marked decrease in ethanol production and in a significant increase in succinate production. Washed cells possessed activity for the cleavage of formate to $\mathrm{CO}_{2}$ and $\mathrm{H}_{2}$, which seemed to play a role in supplying $\mathrm{CO}_{2}$ for the synthesis of succinate in the absence of bicarbonate. The study of enzyme activities in cell-free extracts suggested that fructose was fermented by the EmbdenMeyerhof-Parnas pathway. The values of $Y_{\text {ATP }}^{\max }$ and the efficiency of ATP generation (ATP-Eff) during fructose catabolism were estimated and higher values were obtained for the culture in the presence of bicarbonate: $20.2 \mathrm{~g}$ dry wt (mol ATP) $)^{-1}$ and $3.0 \mathrm{~mol}$ ATP (mol fructose) $)^{-1}$, respectively, versus $Y_{\mathrm{ATP}}^{\max }=15 \cdot 1$ and ATP-Eff $=2.7$ in the absence of bicarbonate.
\end{abstract}

\section{INTRODUCTION}

Actinobacillus actinomycetemcomitans is a Gram-negative, facultatively anaerobic, small coccobacillus (Phillips, 1984). In the human oral cavity the organism is isolated mainly from dental plaque and periodontal pockets (Slots et al., 1980). A. actinomycetemcomitans possesses a number of pathogenic properties, including the ability to produce leukotoxin (Tsai et al., 1984; Ohta et al., 1987), lymphocyte suppressive factor (Shenker et al., 1982a), a biologically active lipopolysaccharide (Kiley \& Holt, 1980; Iino \& Hopps, 1984), and fibroblast inhibitory factor (Shenker et al., 1982b). Although clinically significant, little is known about the growth characteristics and basic physiology of the organism other than its requirement for $\mathrm{CO}_{2}$ for aerobic growth (Thjotta \& Sydnes, 1951; Holm, 1954; Slots, 1982) and its fermentation of several carbohydrates (Pulverer \& Ko, 1970; Slots, 1982). Among these characteristics, it is of interest to note the $\mathrm{CO}_{2}$-stimulated growth of $A$. actinomycetemcomitans since the oral environment contains high concentrations of bicarbonate, the hydrated form of $\mathrm{CO}_{2}$ (Jenkins, 1978). The $\mathrm{CO}_{2}$-dependent or -stimulated fermentation of carbohydrate has been reported with several facultative or obligate anaerobes, including Cytophaga succinicans (Anderson \& Ordal, 1961), Bacteroides ruminicola (White et al., 1962), B. fragilis (Macy et al., 1978), Actinomyces naeslundii (Buchanan \& Pine, 1967) and Capnocytophaga ochracea (Kapke et al., 1980), and with phototrophic, purple, nonsulphur bacteria (Schultz \& Weaver, 1982; Hiraishi, 1988a). In the metabolism of these bacteria, $\mathrm{CO}_{2}$ functions by providing, through condensation with phosphoenolpyruvate or pyruvate, $\mathrm{C}_{4}$ dicarboxylic acids which can serve as acceptors for the electrons generated in carbohydrate degradation.

Abbreviations: ATP-Eff, efficiency of ATP generation; $D$, dilution rate; PEP, phosphoenolpyruvate. 
The purpose of the present study was to examine in more detail the anaerobic, fermentative growth of A. actinomycetemcomitans in fructose-limited chemostat cultures, particularly with regard to the effect of bicarbonate.

\section{METHODS}

Organism and medium. A. actinomycetemcomitans 301-b, used in this study, was isolated from a patient with rapidly progressive periodontitis (Ohta et al., 1986, 1987). The growth medium (AA medium) contained the following ingredients $\left(\mathrm{g} \mathrm{l}^{-1}\right)$ : $\mathrm{Na}_{2} \mathrm{SO}_{4}(0 \cdot 5), \mathrm{KH}_{2} \mathrm{PO}_{4}(0 \cdot 2), \mathrm{MgCl}_{2} \cdot 6 \mathrm{H}_{2} \mathrm{O}(0 \cdot 4), \mathrm{NaCl}(1 \cdot 2), \mathrm{NH}_{4} \mathrm{Cl}(0 \cdot 3), \mathrm{KCl}$ $(0 \cdot 3), \mathrm{CaCl}_{2}(0 \cdot 11)$, Bacto yeast extract $(2 \cdot 0)$, resazurin $(0 \cdot 001)$, and Tris (6.05). The trace element solution described previously (Ohta \& Gottschal, 1988) was also added. After the medium had been adjusted to $\mathrm{pH} 7 \cdot 3-7 \cdot 4$ and autoclaved, separately autoclaved solutions of fructose (final concentration $1.8 \mathrm{~g} \mathrm{l}^{-1}$ ) were added to the medium aseptically. To examine the effect of bicarbonate, an autoclaved solution of $\mathrm{NaHCO}_{3}$ (final concentration $4 \mathrm{~g} \mathrm{l}^{-1}$ ) was added to the medium. This bicarbonate concentration had been found to be saturated by batch culture experiments (unpublished results).

Continuous culture. The anaerobic chemostat cultures were performed as described previously (Laanbroek, 1978; Ohta \& Gottschal, 1988). The system was maintained under a stream $\left(300 \mathrm{ml} \mathrm{h}^{-1}\right)$ of anaerobic gases $(100 \%$ $\mathrm{N}_{2}$ or $90 \% \mathrm{~N}_{2} / 10 \% \mathrm{CO}_{2}$ ) which were freed of traces of oxygen by passage over hot copper filings; $\mathrm{N}_{2}$ was used for the cultures without the addition of bicarbonate and $\mathrm{N}_{2} / \mathrm{CO}_{2}$ for the cultures supplemented with bicarbonate. Cultures were kept at $37^{\circ} \mathrm{C}$ and at $\mathrm{pH} 7.0$ with automatic additions of $2 \mathrm{M}-\mathrm{NaOH}$ or $1 \mathrm{M}-\mathrm{HCl}$. The turbidity of cultures was measured in a $1 \mathrm{~cm}$ cuvette in an LKB Novaspec 4049 spectrophotometer. The purity of the cultures was checked every day by observing the cells microscopically or inoculating culture samples on trypticase soy broth agar (BBL) and incubating them aerobically; A. actinomycetemcomitans exhibited scant growth on this medium in air unless $\mathrm{CO}_{2}$ was supplemented (Slots, 1982).

Chemical analysis. Acid end products (formate, acetate, lactate and succinate) and ethanol were determined by gas-liquid chromatography (GC) using Hitachi 163 and Shimadzu GC-R1A gas chromatographs. Samples were prepared as described by Holdeman et al. (1977). Acid end products were analysed under the following conditions: column, $3 \mathrm{~mm} \times 2 \mathrm{~m}$ glass column packed with $10 \%$ Thermon-1000/1\% $\mathrm{H}_{3} \mathrm{PO}_{4}$ on Chromosorb W/HP $(80-100$ mesh) (Shimadzu); oven temperature, isothermal at $160{ }^{\circ} \mathrm{C}$ for the analysis of acetate, or at $155^{\circ} \mathrm{C}$ for lactate and succinate, and at $60^{\circ} \mathrm{C}$ for formate; carrier gas, $\mathrm{N}_{2}$ at $50 \mathrm{ml} \mathrm{min}-1$; injector temperature, $220^{\circ} \mathrm{C}$; detector, flame ionization detector. For the analysis of ethanol, the following conditions were used: column, $3 \mathrm{~mm} \times 1 \mathrm{~m}$ glass column packed with Adsorb P-1 (60-80 mesh) (Nishio Kogyo, Tokyo, Japan); oven temperature, isothermal at $150{ }^{\circ} \mathrm{C}$; carrier gas, $\mathrm{N}_{2}$ at $20 \mathrm{ml} \mathrm{min}{ }^{-1}$; injector temperature, $210^{\circ} \mathrm{C}$; detector, flame ionization detector. $\mathrm{H}_{2}$ and $\mathrm{CO}_{2}$ were also analysed by $\mathrm{GC}$ with a thermal conductivity detector. The gas chromatograph was equipped with either stainless steel columns $(3 \mathrm{~mm} \times 2 \mathrm{~m})$ packed with a $5 \mathrm{~A}$ molecular sieves (Shimadzu) for the analysis of $\mathrm{H}_{2}$ or packed with Porapak Q (Waters Associates, Milford, USA) for $\mathrm{CO}_{2}$. Fructose was determined by the enzymic method described by Beutler (1984). Cell dry weight was determined by centrifuging $50 \mathrm{ml}$ of culture at $12000 \mathrm{~g}$ for $15 \mathrm{~min}$ and washing the cell pellets with phosphate-buffered saline (PBS; pH 7.0) which contained $\left(\mathrm{g}^{-1}\right) \mathrm{NaCl}^{-}$ (6.8), $\mathrm{Na}_{2} \mathrm{HPO}_{4}(1 \cdot 2)$, and $\mathrm{KH}_{2} \mathrm{PO}_{4}(0 \cdot 7)$. The pellets were collected on preweighed $0.45 \mu \mathrm{m}$-pore size nitrocellulose membrane filters (Advantec Toyo, Tokyo, Japan), dried at $105^{\circ} \mathrm{C}$ and reweighed. The relationship between cell concentration and the $\mathrm{OD}_{660}$ in $1 \mathrm{~cm}$ optical cuvettes was linear up to 0.6 unit of $\mathrm{OD}_{660}$. The correlation coefficient of cell dry weight with $\mathrm{OD}_{660}$ did not vary significantly for cultures run at different dilution rates. Thus, the coefficient was averaged as $0.852 \pm 0.055 \mathrm{mg}$ dry weight $\mathrm{ml}^{-1}$ per $\mathrm{OD}_{660}$ unit (mean $\pm \mathrm{SD}$ of 12 runs) and used to determine the cell density in the culture and washed-cell suspensions.

Washed-cell experiments. The consumption of formate and the concomitant production of $\mathrm{CO}_{2}$ and $\mathrm{H}_{2}$ by washed cells were determined. Bacterial cells were taken from the chemostat under a constant flow of $\mathbf{N}_{2}$ and transferred into a centrifuge bottle filled with $\mathrm{N}_{2}$. After centrifugation $(12000 \mathrm{~g}, 20 \mathrm{~min})$, the cell pellets were washed twice with a $\mathrm{N}_{2}$-gassed solution (T solution) containing $50 \mathrm{mM}$-Tris/ $\mathrm{HCl}$ buffer $\left(\mathrm{pH} 7 \cdot 5\right.$ ), $30 \mathrm{mM}-\mathrm{KH}_{2} \mathrm{PO}_{4}$, $66 \mathrm{mM}-\mathrm{NaCl}, 5 \mathrm{mM}-\mathrm{KCl}, 2 \mathrm{mM}-\mathrm{CaCl}_{2}, 10 \mathrm{mM}-\mathrm{MgCl}_{2} \cdot 6 \mathrm{H}_{2} \mathrm{O}$, and $2 \mathrm{~mm}$-dithiothreitol (DTT). The washed cells were suspended in $\mathrm{T}$ solution at $30-50 \mathrm{mg} \mathrm{dry} \mathrm{wt} \mathrm{ml}^{-1}$ and stored in ice until used. Washed-cell experiments were performed anaerobically at $37^{\circ} \mathrm{C}$ in $8 \mathrm{ml}$ tubes sealed with a butyl rubber septum. After transferring the cell suspension (2-3 $\mathrm{ml}$ in $\mathrm{T}$ solution, concentrations as indicated in Results), the tube was repeatedly evacuated and filled with $\mathrm{N}_{2}$. The reactions were started by the addition of formate via syringes and stopped by adding $0 \cdot 2 \mathrm{ml}$ of $10 \%(\mathrm{v} / \mathrm{v}) \mathrm{H}_{2} \mathrm{SO}_{4}$. The amounts of formate, $\mathrm{CO}_{2}$ and $\mathrm{H}_{2}$ were determined by GC.

Preparation of cell-free extracts. Bacterial cells were collected and washed as described above: PBS supplemented with 2 mM-DTT was substituted for T solution. The washed cells were suspended in $\mathrm{N}_{2}$-gassed $50 \mathrm{mM}$-Tris/HCl buffer (pH 7.5) containing $4 \mathrm{mM}-\mathrm{DTT}$ at $10-15 \mathrm{mg}$ dry $\mathrm{wt} \mathrm{ml}^{-1}$. The suspension was sonified 812 times for $15 \mathrm{~s}$ with $2 \mathrm{~min}$ intervals using an ultrasonic disruptor (UR-200P; Tomy Seiko, Tokyo, Japan) under a constant flow of $\mathrm{N}_{2}$. During sonification, the cell suspensions were kept on ice. The sonicated suspension was 
gassed briefly with $\mathrm{N}_{2}$ and centrifuged at $12000 \mathrm{~g}$ for $15 \mathrm{~min}$. The supernatant was transferred to sealed vials containing $\mathrm{N}_{2}$ gas. This supernatant ('cell extract') was kept on ice and used immediately for the enzyme assay. Protein was measured by the method of Lowry using bovine serum albumin as standard.

Enzyme assays. The following enzymes were assayed spectrophotometrically with a Beckman DU-8B UVvisible spectrophotometer. Assays were performed at $25^{\circ} \mathrm{C}$ in either $1.0 \mathrm{ml}$ normal open cuvettes or $1.0 \mathrm{ml}$ cuvettes sealed with a butyl rubber stopper. The latter ('anaerobic') cuvettes containing a reaction mixture and $\mathrm{N}_{2}$ gas were used for the assay of pyruvate formate-lyase (EC 2.3.1.54) and fumarate reductase. $50 \mathrm{mM}-\mathrm{Tris} / \mathrm{HCl}$ buffer ( $\mathrm{pH} \mathrm{7.5)} \mathrm{was} \mathrm{used} \mathrm{unless} \mathrm{otherwise} \mathrm{indicated.} \mathrm{The} \mathrm{reactions} \mathrm{were} \mathrm{generally} \mathrm{started} \mathrm{by} \mathrm{the} \mathrm{addition} \mathrm{of} \mathrm{cell}$ extract (between 5 and $100 \mu \mathrm{l}$, at a concentration of $0.02-0.2 \mathrm{mg}$ protein $\mathrm{ml}^{-1}$ ). Reaction rates were calculated from the change in $A_{340}$ due to the reduction of NADP or the oxidation of NADH $\left(\varepsilon=6.3 \mathrm{mM}^{-1} \mathrm{~cm}^{-1}\right)$ unless otherwise indicated. Activities were determined in a range of linearity between the reaction rate and the protein concentration.

Glucokinase (EC 2.7.1.2) was assayed by the method of Pilkis (1975). Glucose-6-phosphate isomerase (EC 5.3.1.9) activity was determined by the method of Gracy \& Tilley (1975). 6-Phosphofructokinase (EC 2.7.1.11) and 1-phosphofructokinase (EC 2.7.1.56) activities were measured as described by Baumann \& Baumann (1975). Fructose-diphosphate aldolase (EC 4.1.2.13) was assayed by the method of Lebherz \& Rutter (1975). Enolase (EC 4.2.1.11) activity was determined by monitoring phosphoenolpyruvate (PEP) production at $240 \mathrm{~nm}$ $\left(\varepsilon=1.5 \mathrm{~mm}^{-1} \mathrm{~cm}^{-1}\right.$ ) according to the procedure of Spring \& Wold (1975). Glucose-6-phosphate dehydrogenase (EC 1.1.1.49) activity was measured in the manner of Olive \& Levy (1975). 6-Phosphogluconate dehydrogenase (EC 1.1.1.44) was assayed by the method of Bridges \& Wittenberger (1975). Phosphoglucomutase (EC 5.4.2.2) and acetate kinase (EC 2.7.2.1) were assayed by the procedures of Bergmeyer et al. (1983). Phosphogluconate dehydratase (EC 4.2.1.12) and 6-phospho-2-keto-3-deoxygluconate aldolase (EC 4.1.2.14) were assayed together as described by van Dijken \& Quayle (1977). The assay for pyruvate kinase (EC 2.7.1.40) was that of Tuominen \& Bernlohr (1975). Lactate dehydrogenase (EC 1.1.1.27) was assayed as described by Wittenberger (1975). For attempts to demonstrate pyruvate formate-lyase activity, the assay was performed in anaerobic cuvettes by coupling the reactions to citrate synthase (EC 4.1.3.7) and malate dehydrogenase (EC 1.1.1.37) as described by Knappe \& Blaschkowski (1975). For attempts to demonstrate PEP- or pyruvate-carboxylating activities, i.e. PEP carboxylase (EC 4.1.1.31), GDP- (EC 4.1.1.32) and ADP-dependent (EC 4.1.1.49) PEP carboxykinase, and pyruvate carboxylase (EC 6.4.1.1), the assays were carried out as described by Scrutton (1971). Malic enzyme (EC 1 1 1 1.40) was assayed according to the procedure of Schobert \& Bowien (1984). Malate dehydrogenase activity was determined as described by Kitto (1969). Fumarate hydratase (EC 4.2.1.2) was assayed by monitoring the production of fumarate at $240 \mathrm{~nm}\left(\varepsilon=2.53 \mathrm{mM}^{-1} \mathrm{~cm}^{-1}\right)$ as described by Hill \& Bradshaw (1969). Fumarate reductase activity was determined anaerobically with reduced methyl viologen $\left(\varepsilon=13.0 \mathrm{mM}^{-1} \mathrm{~cm}^{-1}\right.$ at $\left.600 \mathrm{~nm}\right)$ as the electron donor according to the procedure of Hiraishi $(1988 \mathrm{~b})$.

Chemicals. All enzymes, nucleotides and cofactors were purchased from Boehringer Mannheim, Sigma or Oriental Yeast, Tokyo, Japan.

\section{RESULTS}

\section{Growth and product formation in fructose-limited cultures}

A. actinomycetemcomitans is able to use several sugars as growth substrates (Pulverer \& Ko, 1970; Slots, 1982). The A. actinomycetemcomitans 301-b used in this study grew with fructose, glucose, maltose, mannitol amd mannose but not with cellobiose, galactose, lactose, raffinose, ribose, rhamnose, sucrose, trehalose and xylose. Fructose was chosen as the growth-limiting nutrient since the growth rate of strain 301-b was higher with fructose than with any other sugars; the specific growth rate, $0.46 \mathrm{~h}^{-1}$ with fructose versus $0.19 \mathrm{~h}^{-1}$ with glucose, in batch cultures was measured using AA medium as a basal medium.

The organism was grown anaerobically in a fructose-limited culture without the addition of bicarbonate at various dilution rates $(D)$. Steady states were obtained at $D$ ranging from 0.04 to $0.25 \mathrm{~h}^{-1}$ and the amounts of fructose consumed and fermentation products were determined. The major fermentation products were formate, acetate, ethanol and succinate, with minor amounts of lactate. The specific rates of fructose consumption $\left(q_{\text {fructose }}\right)$ and formation of all products at each steady state were calculated (Table 1). A plot of $q_{\text {fructose }}$ against $D$ yielded a straight line (Fig. 1). Assuming the following relationship (Pirt, 1975):

$$
q_{\text {fructose }}=D / Y_{\text {fructose }}^{\max }+m_{\text {fructose }}
$$

the maximum growth yield ( $\left.Y_{\text {fructose }}^{\max }\right)$ and the maintenance coefficient ( $m_{\text {fructose }}$ ) were estimated as $40.3 \mathrm{~g}$ dry wt (mol fructose) $)^{-1}$ and $0.248 \mathrm{mmol}(\mathrm{g} \text { dry wt})^{-1} \mathrm{~h}^{-1}$, respectively. 


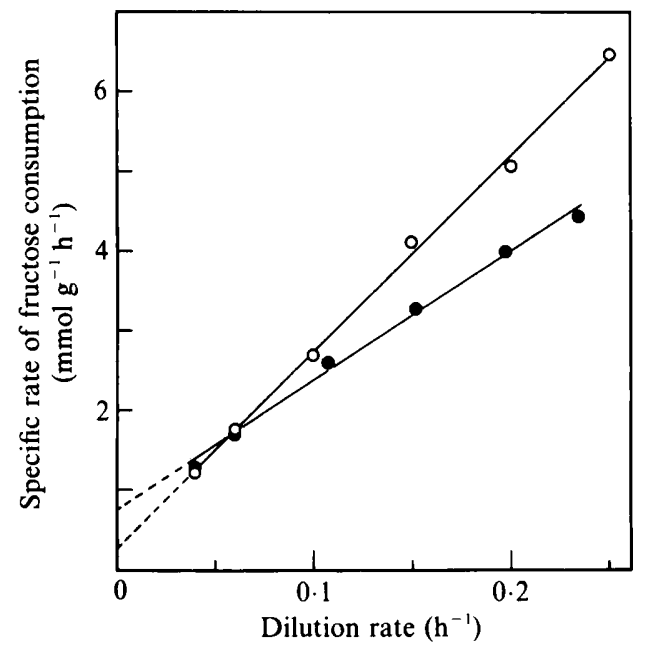

Fig. 1. Relationship between growth rate and specific rate of fructose consumption $\left(q_{\text {fructose }}\right)$ of anaerobic fructose-limited chemostat cultures of $A$. actinomycetemcomitans $301-b$. Cultures were grown at $37^{\circ} \mathrm{C}, \mathrm{pH} 7 \cdot 0$, in the absence $(O)$ and presence $(\odot)$ of $48 \mathrm{~mm}$-bicarbonate.

Table 1. Steady-state values for the rates of fructose consumption and product formation in fructose-limited anaerobic chemostat cultures of A. actinomycetemcomitans 301-b at various $D$ values in the absence of bicarbonate

The chemostat culture was run at $37^{\circ} \mathrm{C}, \mathrm{pH} 7 \cdot 0$. Specific rates $(q)$ are expressed in mmol $(\mathrm{g} \mathrm{dry} \mathrm{wt})^{-1}$ $\mathrm{h}^{-1}$.

Dilution rate $\left(\mathrm{h}^{-1}\right)$

No. of runs

Input fructose (mM)

Residual fructose (mM)

$q_{\text {fructose }}$

$q_{\text {formate }}$

$q_{\text {acetate }}$

$q_{\text {ethanol }}$

$q_{\text {lactate }}$

$q_{\text {succinate }}$

$Y_{\text {fructose }}\left(\mathrm{g} \mathrm{mol}^{-1}\right)$

Carbon balance $(\%)$

Fructose carbon

Product carbon (P)

Cell carbon $(\mathrm{C}) \dagger$

Recovery $(P+C)$

Redox-balanceł

$\begin{array}{cc}0.04^{*} & 0.06 \\ 2 & 1 \\ 10.3 & 10.1 \\ <0.1 & <0.1 \\ 1.21 & 1.76 \\ 0.10 & 0.51 \\ 0.96 & 1.43 \\ 0.25 & 0.30 \\ <0.01 & <0.02 \\ 0.74 & 1.18 \\ 33.0 & 34.0\end{array}$

$\begin{array}{cc}100 & 100 \\ 75 & 82 \\ 23 & 24 \\ 98 & 106 \\ 0.82 & 0.84\end{array}$

$0 \cdot 10^{*}$
4
$9 \cdot 6-10 \cdot 1$
$<0 \cdot 1$
$2 \cdot 67 \pm 0 \cdot 17$
$1 \cdot 47 \pm 0 \cdot 13$
$2 \cdot 27 \pm 0.05$
$0.96 \pm 0.11$
$0 \cdot 03 \pm 0.03$
$1 \cdot 28 \pm 0.05$
$37.5 \pm 0.6$

100
$82 \pm 2$
$26 \pm 0$
$108 \pm 2$
0.84

$0 \cdot 15$
1
$10 \cdot 1$
$<0 \cdot 1$
$4 \cdot 12$
$4 \cdot 41$
$3 \cdot 46$
$2 \cdot 14$
$0 \cdot 12$
$1 \cdot 24$
$36 \cdot 4$

100

85

25

110

0.83

$\begin{array}{cc}0.20^{*} & 0.25 \\ 3 & 1 \\ 10 \cdot 3 & 9.6 \\ <0 \cdot 1 & 1.9 \\ 5.07 \pm 0.4 & 6.47 \\ 5.03 \pm 0.3 & 10 \cdot 17 \\ 3.86 \pm 0.15 & 4.47 \\ 2.84 \pm 0.15 & 3.43 \\ 0.15 \pm 0.09 & 2.07 \\ 0.71 \pm 0.15 & 0.32 \\ 39.4 \pm 0.5 & 38.6\end{array}$

$\begin{array}{cc}100 & 100 \\ 71 \pm 2 & 86 \\ 27 \pm 1 & 27 \\ 98 \pm 3 & 113 \\ 0 \cdot 71 & 0.74\end{array}$

* The values at these dilution rates are expressed as means or means $\pm \mathrm{SD}$.

+ Cell carbon was assumed as $50 \%$ of dry cell weight.

$\ddagger$ Redox-balance $\left(2 q_{\text {ethanol }}+q_{\text {lactate }}+2 q_{\text {succinate }}\right) / 2 q_{\text {fructose }}$.

A substrate amount of bicarbonate $(0.4 \%, 48 \mathrm{~mm})$ was added to the fructose-limited medium and the chemostat culture was run at $D$ values between 0.04 and $0.23 \mathrm{~h}^{-1}$ (Table 2). The $q_{\text {fructose }}$ also varied linearly with $D$ (Fig. 1). The estimated values of $Y_{\text {fructose }}^{\max }$ and $m_{\text {fructose }}$ were $61.7 \mathrm{~g} \mathrm{dry}$

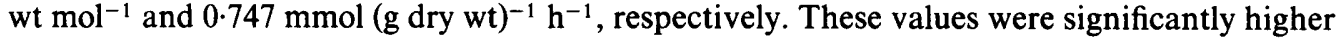
than those in the absence of bicarbonate. Consequently, it is expected that there is a significant difference between the efficiency of energy conservation or of energy utilization for biomass 
Table 2. Steady-state values for the rates of fructose consumption and product formation in fructose-limited anaerobic chemostat cultures of A. actinomycetemcomitans 301-b at various $D$ values in the presence of $48 \mathrm{~mm}$ bicarbonate

The chemostat culture was run at $37^{\circ} \mathrm{C}, \mathrm{pH} \mathrm{7 \cdot 0}$. Specific rates $(q)$ are expressed in mmol $(\mathrm{g} \text { dry wt })^{-1}$ $\mathrm{h}^{-1}$.

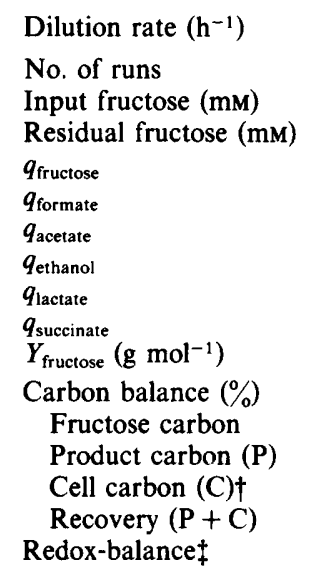

$\begin{array}{cc}0.04 & 0.06 \\ 1 & 1 \\ 9.9 & 9.9 \\ <0.1 & <0.1 \\ 1.28 & 1.72 \\ 0.81 & 1.50 \\ 1.20 & 1.64 \\ 0.12 & 0.14 \\ 0.04 & <0.02 \\ 1.21 & 1.59 \\ 31 \cdot 1 & 34.8 \\ & \\ 100 & 100 \\ 108 & 110 \\ 22 & 24 \\ 130 & 134 \\ 1.05 & 1.01\end{array}$

0.11
1
9.9
$<0.1$
2.60
2.73
2.43
0.16
$<0.03$
2.51
40.7

0.15
1
9.9
$<0.1$
3.23
3.71
2.94
0.23
$<0.03$
2.77
46.5

100
111
28
139
1.03

100
109
32
141
0.93

* The values at this dilution rate are expressed as means. $\dagger$ Cell carbon was assumed as $50 \%$ of dry cell weight. $\ddagger$ Redox-balance $\left(2 q_{\text {ethanol }}+q_{\text {lactate }}+2 q_{\text {succinate }}\right) / 2 q_{\text {fructose }}$.

formation during the growth in the absence and presence of bicarbonate. As shown in Table 2, a marked decrease in $q_{\text {ethanol }}$ and a significant increase in $q_{\text {succinate }}$ were evident at $D$ below $0.15 \mathrm{~h}^{-1}$ with the addition of bicarbonate. However, $q_{\text {succinate }}$ decreased with $D$ at $D$ above $0 \cdot 15 \mathrm{~h}^{-1}$. This phenomenon was not due to bicarbonate-limitation because the amount of bicarbonate consumed was roughly estimated as $52-78 \%$ of that added based on the carbon recovery data. Furthermore, the culture was kept under a stream of anaerobic gas containing $10 \% \mathrm{CO}_{2}$.

The accumulation of residual fructose was observed at $D$ values of $0 \cdot 23-0.25 \mathrm{~h}^{-1}$ (Tables 1 and 2 ), although these $D$ values were approximately half the maximum growth rate. Possibly, this was due to either the low apparent affinity for fructose $\left(K_{\mathrm{s}}\right)$ or the limitation by some other nutrients. If the former was the case, the $K_{\mathrm{s}}$ value was estimated to be $1.6-2.4 \mathrm{~mm}$ from the Monod equation (Pirt, 1975). At present we do not have satisfactory data to decide whether the growth is limited by some other nutrient at $D$ values of $0.23-0.25 \mathrm{~h}^{-1}$.

\section{$\mathrm{CO}_{2}$ formation during fructose catabolism}

As in the mixed acid producers such as Escherichia coli (Doelle, 1975), it is expected that the cleavage of pyruvate to acetyl-CoA and formate and that of formate to $\mathrm{CO}_{2}$ and $\mathrm{H}_{2}$ occurs in $A$. actinomycetemcomitans. The former reaction is catalysed by pyruvate formate-lyase and the latter by formate hydrogen-lyase complex (i.e. formate dehydrogenase and hydrogenase). To demonstrate these activities, hypophosphite, a formate analogue and a potent inhibitor of pyruvate formate-lyase (Thauer et al., 1972; Hiraishi, 1988a), was added to a steady state of the fructose-limited chemostat culture run at $D=0.20 \mathrm{~h}^{-1}$ in the absence of bicarbonate and changes in the cell density and the amount of the end products were then followed. The results shown in Fig. 2 indicate that hypophosphite partially inhibited growth and blocked the production of acetate, ethanol and formate but stimulated that of lactate. The washout rate of acetate plus ethanol was equal to $D$, clearly indicating that pyruvate formate-lyase was the major enzyme catalysing the cleavage of pyruvate in the fructose catabolism.

Fig. 2 shows that the washout rate of formate $\left(0.27 \mathrm{~h}^{-1}\right)$ was higher than $D\left(0.20 \mathrm{~h}^{-1}\right)$, suggesting the presence of a formate-decomposing reaction. This reaction was confirmed by 


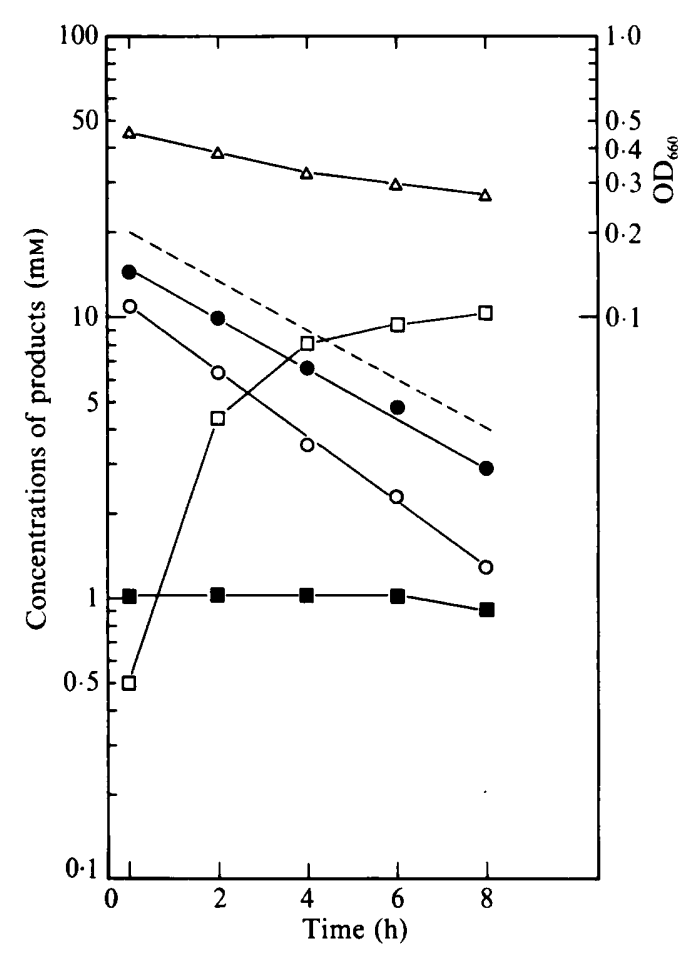

Fig. 2. Changes in the amounts of fermentation products and cell density of A. actinomycetemcomitans 301-b growing in a fructose-limited chemostat culture after the addition of 20 mM-sodium hypophosphite to the culture. The culture was grown at $37^{\circ} \mathrm{C}, \mathrm{pH} 7 \cdot 0$, in the absence of bicarbonate. The amounts of formate $(O)$, acetate plus ethanol $(\bullet)$, lactate $(\square)$, succinate $(\square)$ and cell density $(\triangle)$ were determined every $2 \mathrm{~h}$ after the addition of hypophosphite. The dashed line represents the theoretical change in the amount of hypophosphite.

washed-cell experiments (Table 3). The washed cells prepared from a fructose-limited chemostat culture run in the absence of bicarbonate consumed formate with the concomitant production of $\mathrm{CO}_{2}$ and $\mathrm{H}_{2}$, indicating the presence of formate hydrogen-lyase complex activity. The amount of $\mathrm{CO}_{2}$ produced was nearly equal to that of the formate consumed $[91 \mathrm{nmol} \mathrm{CO}$ $(\mathrm{mg} \text { dry wt) })^{-1}$ versus $94 \mathrm{nmol}$ formate $(\mathrm{mg} \mathrm{dry} \mathrm{wt})^{-1}$ in $30 \mathrm{~min}$ incubation at $37^{\circ} \mathrm{C}$ ] although the amount of $\mathrm{H}_{2}$ produced was lower [ $55 \mathrm{nmol} \mathrm{H}_{2}(\mathrm{mg} \text { dry wt })^{-1}$ ] than the amount of formate consumed. The activity of formate cleavage was measured as $3.0 \mathrm{nmol} \mathrm{min}-1$ (mg dry wt $)^{-1}$ with washed cells from a culture at $D=0.25 \mathrm{~h}^{-1}$. With washed cells from a culture at lower $D$ $\left(0 \cdot 10 \mathrm{~h}^{-1}\right)$, a higher activity was obtained: $\left.44 \mathrm{nmol} \mathrm{m^{-1 } ( \mathrm { mg } \text { dry wt) }}\right)^{-1}$ (mean of duplicate determinations).

\section{Enzyme activity of $A$. actinomycetemcomitans}

Enzyme activities involved in fructose catabolism were determined in cell extracts prepared from cultures run at $D$ values of $0.04 \mathrm{~h}^{-1}$ and $0.25 \mathrm{~h}^{-1}$ in the presence of bicarbonate (Table 4). Cell extracts contained the key enzyme activities of the Embden-Meyerhof-Parnas pathway, i.e. 6-phosphofructokinase, fructose-diphosphate aldolase, enolase and pyruvate kinase. They also contained glucose-6-phosphate dehydrogenase and 6-phosphogluconate dehydrogenase activities, which are involved in the pentose phosphate pathway. No activities were detected for the key enzymes of the Entner-Douderoff pathway, i.e. phosphogluconate dehydratase and 6-phospho-2-keto-deoxygluconate aldolase.

All attempts to detect pyruvate formate-lyase activity in cell extracts were unsuccessful although its presence in growing cells was shown from the results presented in Fig. 2. Attempts 
Table 3. Activity of the cleavage of formate to $\mathrm{CO}_{2}$ and $\mathrm{H}_{2}$ in washed cells of $\mathrm{A}$. actinomycetemcomitans 301-b grown in fructose-limited culture at a $D=0 \cdot 25 h^{-1}$ in the absence of bicarbonate

Washed cells were incubated at $37^{\circ} \mathrm{C}$ for 30 min under strictly anaerobic conditions.

\begin{tabular}{|c|c|c|c|c|}
\hline \multirow{3}{*}{$\begin{array}{l}\text { Amount of cells } \\
\text { (mg dry wt) }\end{array}$} & \multicolumn{4}{|c|}{ Amount $(\mu \mathrm{mol})$ of } \\
\hline & \multicolumn{2}{|c|}{ Formate } & \multirow[b]{2}{*}{$\mathrm{CO}_{2}$ formed } & \multirow[b]{2}{*}{$\mathrm{H}_{2}$ formed } \\
\hline & Added & $\widehat{\text { Used }}$ & & \\
\hline 0 & $29 \cdot 1$ & 0 & 0 & 0 \\
\hline 16 & 27.8 & 1.4 & 1.6 & 1.0 \\
\hline 32 & 28.0 & 3.2 & 2.6 & 1.5 \\
\hline 32 & 0 & 0 & 0.1 & 0.2 \\
\hline
\end{tabular}

Table 4. Enzyme activities in cell extracts of A. actinomycetemcomitans 301-b grown anaerobically in fructose-limited chemostat culture with $48 \mathbf{m m}_{\mathrm{m}}$ bicarbonate at $D$ values of 0.04 and 0.25

\begin{tabular}{|c|c|c|}
\hline \multirow[b]{2}{*}{ Enzyme } & \multicolumn{2}{|c|}{$\begin{array}{l}\text { Specific enzyme activity } \\
{\left[\mathrm{nmol} \min ^{-1}(\mathrm{mg} \text { protein })^{-1}\right]}\end{array}$} \\
\hline & $0 \cdot 04$ & $0 \cdot 25$ \\
\hline Glucokinase & 38 & 36 \\
\hline Phosphoglucomutase & 292 & 371 \\
\hline Glucose-6-phosphate isomerase & 1310 & 1120 \\
\hline 1-Phosphofructokinase & 120 & 137 \\
\hline 6-Phosphofructokinase & 78 & 107 \\
\hline Fructose-diphosphate aldolase & 192 & 147 \\
\hline Enolase & 1030 & 1330 \\
\hline Pyruvate kinase & 67 & 90 \\
\hline Glucose-6-phosphate dehydrogenase & 63 & 48 \\
\hline 6-Phosphogluconate dehydrogenase & 76 & 52 \\
\hline Lactate dehydrogenase & 811 & 500 \\
\hline Acetate kinase & 2990 & 6290 \\
\hline Malate dehydrogenase & 1500 & 772 \\
\hline Fumarate hydratase & 1620 & 1140 \\
\hline Fumarate reductase & 1090 & 512 \\
\hline
\end{tabular}

were also unsuccessful to detect the enzyme activities for the carboxylation of PEP or pyruvate, i.e. PEP carboxylase, GDP- and ADP-dependent PEP carboxykinase and pyruvate carboxylase. NADP-dependent malic enzyme could be detected which required monovalent cations; $\mathrm{NH}_{4}^{+}$was the most effective (data not shown). All of the other activities for the formation of succinate, i.e. malate dehydrogenase, fumarate hydratase and fumarate reductase activities, were easily detected. These enzyme activities in the cell extracts from a culture at $D=$ $0.25 \mathrm{~h}^{-1}$ were significantly lower than those at a lower $D\left(0.04 \mathrm{~h}^{-1}\right)$. By contrast, the acetate kinase activity at $D=0.25 \mathrm{~h}^{-1}$ was about twice as high as that at the lower $D$. Thus, the decrease in $q_{\text {succinate }}$ in a culture with increasing $D$ over $0.15 \mathrm{~h}^{-1}$ (Table 2) was explained by the decrease in the enzyme activity for the succinate-forming pathway.

\section{DISCUSSION}

The addition of bicarbonate to the fructose-limited medium resulted in a significant increase in the $Y_{\text {fructose }}^{\max }$ value (Fig. 1). To interpret this increase, this discussion focuses mainly on (1) the catabolic pathway of fructose and (2) the estimation of the efficiency of ATP generation during fructose fermentation and of $Y_{\mathrm{ATP}}^{\max }$ in the absence and presence of bicarbonate. 


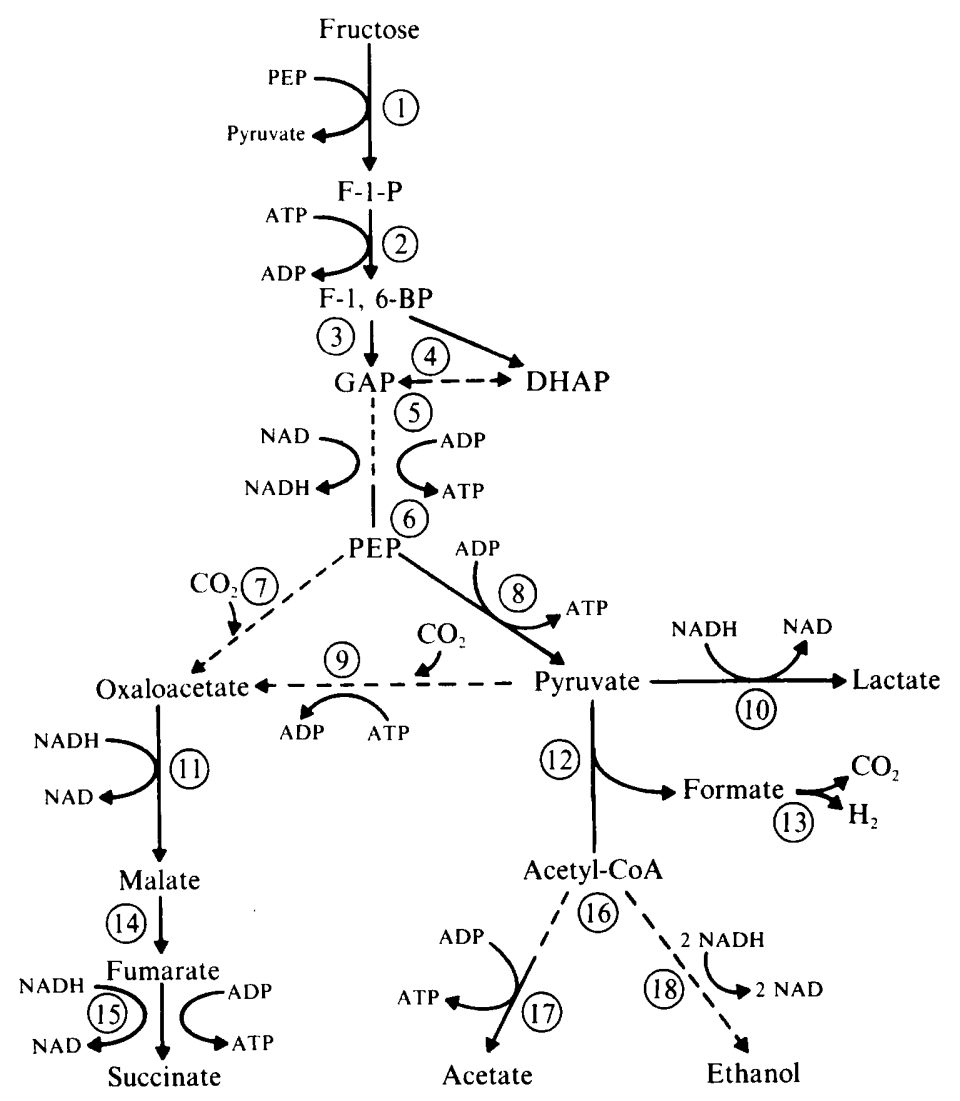

Fig. 3. Probable pathway of fructose catabolism in A. actinomycetemcomitans 301-b. Solid lines indicate the enzyme activities which were demonstrated and dashed lines indicate those not yet determined. F-1-P, fructose-1-phosphate; F-1,6-BP, fructose-1,6-bisphosphate; GAP, glyceraldehyde3-phosphate; DHAP, dihydroxyacetone-phosphate; PEP, phosphoenolpyruvate; Acetyl-CoA, acetylcoenzyme A. (1) PEP : fructose phosphotransferase system; (2) 1-phosphofructokinase; (3) fructosebisphosphate aldolase; (4) triose phosphate isomerase; (5) glyceraldehyde-3-phosphate dehydrogenase, 3-phosphoglycerate kinase, and phosphoglyceromutase; (6) enolase; (7) PEP carboxylase; (8) pyruvate kinase ; (9) pyruvate carboxylase; (10) lactate dehydrogenase; (11) malate dehydrogenase ; (12) pyruvate formate-lyase; (13) formate hydrogen-lyase complex; (14) fumarate hydratase; (15) fumarate reductase; (16) phosphate acetyltransferase; (17) acetate kinase; (18) acetaldehyde dehydrogenase and alcohol dehydrogenase.

The composition of metabolic end products (Tables 1 and 2), the growth inhibition with hypophosphite (Fig. 2), and enzyme activities involved in fructose catabolism (Tables 3 and 4) suggest a fructose fermentation pathway for A. actinomycetemcomitans as shown in Fig. 3 . Fructose-6-phosphate formation from fructose and ATP could not be detected in cell extracts. Instead, 1-phosphofructokinase activity was detected (Table 4), suggesting that the initial step in fructose catabolism is the formation of fructose 1-phosphate, probably catalysed by the PEP : fructose phosphotransferase system. The presence of this system was partly confirmed by measuring the rate of the fructose-dependent conversion of PEP to pyruvate with permeabilized cells according to the method of Kornberg \& Reeves (1979); the rate was $4.1 \mathrm{nmol}$ pyruvate formed $\min ^{-1}$ (mg cell protein $)^{-1}$ in cells from a fructose-limited chemostat culture run at $D=0 \cdot 1 \mathrm{~h}^{-1}$ in the absence of bicarbonate (data not shown). Fructose 1-phosphate is catabolized primarily by the Embden-Meyerhof-Parnas pathway to yield PEP or pyruvate, which may then be either carboxylated to oxaloacetate or converted to acetyl-CoA. 
All attempts to detect any activity for PEP carboxylase, GDP- and ADP-dependent PEP carboxykinases and pyruvate carboxylase in cell extracts were unsuccessful. The identification of enzyme activities involved in the carboxylation of PEP or pyruvate by cell extracts is often difficult because of the possible mutual interference of these activities (Schobert \& Bowien, 1984). Therefore, to identify the activity, it will be necessary to perform radiometric assay using labelled bicarbonate. Difficulty was also encountered in demonstrating pyruvate formate-lyase activity in cell extracts, possibly because of its hypersensitivity to oxygen as described with the enzymes of E. coli (Knappe \& Blaschkowski, 1975) and Streptococcus mutans (Yamada et al., 1985). However, the exclusive function of pyruvate formate-lyase in the cleavage of pyruvate to formate and acetyl-CoA is strongly suggested in anaerobically grown cells from the results shown in Fig. 2.

ATP was possibly gained at four different steps catalysed by phosphoglycerate kinase (EC 2.7.2.3), pyruvate kinase, acetate kinase and fumarate reductase. The coupling of fumarate reduction and electron-transport-linked phosphorylation in this organism is expected from the work of Mannheim et al. (1978). They reported that Actinobacillus and Pasteurella organisms including $A$. actinomycetemcomitans are capable of using both aerobic respiration and desmethylmenaquinone-mediated fumarate respiration as energy-yielding pathways.

The activity for the cleavage of formate to $\mathrm{CO}_{2}$ and $\mathrm{H}_{2}$, possibly formate hydrogen-lyase complex activity, was revealed with washed cells (Table 3). Thus, it is expected that $\mathrm{CO}_{2}$ is produced from formate and then fixed for the succinate synthesis in the culture in the absence of bicarbonate. The specific rate of $\mathrm{CO}_{2}$ and $\mathrm{H}_{2}$ formation $\left(q_{\mathrm{CO}_{2}+\mathrm{H}}\right)$ in a steady-state culture can be estimated from the following equation:

$$
q_{\mathrm{CO}_{2}+\mathrm{H}_{2}}=q_{\text {acetate }}+q_{\text {ethanol }}-q_{\text {formate }}
$$

To compare rates of $\mathrm{CO}_{2}$ formation and succinate synthesis in the culture, the ratio of $q_{\text {succinate }}$ to $q_{\mathrm{CO}_{2}+\mathrm{H}_{2}}$ was calculated. The value ranged from 0.7 to 1.0 at $D$ below $0.15 \mathrm{~h}^{-1}$ and was 0.4 at $D=0.20 \mathrm{~h}^{-1}$. From these calculations, it seems that at $D$ below $0.15 \mathrm{~h}^{-1}$, the $\mathrm{CO}_{2}$ production was nearly coupled to the $\mathrm{CO}_{2}$ fixation. At $D$ above $0 \cdot 20 \mathrm{~h}^{-1}$, this was not the case because of the lowered enzyme activities for the succinate-synthesis pathway (Table 4) and the lowered activities for the cleavage of formate from $44 \mathrm{nmol} \mathrm{min}^{-1}(\mathrm{mg} \text { dry wt })^{-1}$ in washed cells from the culture at $D=0.10 \mathrm{~h}^{-1}$ to $3 \mathrm{nmol} \mathrm{min}-1$ (mg dry wt) $)^{-1}$ at $D=0.25 \mathrm{~h}^{-1}$. In addition, the $q_{\mathrm{CO}_{2}+\mathrm{H}_{2}}$ value at $D=0.25 \mathrm{~h}^{-1}$ was negative. A satisfactory interpretation for this is not available at present.

As in mixed acid producers such as Klebsiella aerogenes (K. pneumoniae) (Streekstra et al., 1987), the fructose catabolism by $A$. actinomycetemcomitans is summed up in the following overall-equations:

$$
\begin{array}{ll}
1 \text { fructose }+2 \mathrm{ADP}+2 \mathrm{NAD} & \rightarrow 2 \text { pyruvate }+2 \mathrm{ATP}+2 \mathrm{NADH} \\
1 \text { pyruvate }+1 \mathrm{ADP} & \rightarrow 1 \text { acetate }+1 \text { formate }+1 \mathrm{ATP} \\
1 \text { pyruvate }+2 \mathrm{NADH} & \rightarrow 1 \text { ethanol }+1 \text { formate }+2 \mathrm{NAD} \\
1 \text { pyruvate }+1 \mathrm{CO}_{2}+2 \mathrm{NADH} & \rightarrow 1 \text { succinate }+2 \mathrm{NAD} \\
1 \text { pyruvate }+1 \mathrm{NADH} & \rightarrow 1 \text { lactate }+1 \mathrm{NAD} \\
1 \text { formate } & \rightarrow 1 \mathrm{H}_{2}+1 \mathrm{CO}_{2}
\end{array}
$$

Although there are two alternative pathways for the succinate synthesis via oxaloacetate from either PEP or pyruvate, the same overall equation as (6) is given for the two pathways. Pyruvate is formally regarded as a major precursor metabolite for the biosynthesis of building blocks (Ingraham et al., 1983). This implies that biomass formation is associated with ATP formation in glycolysis during the formation of pyruvate (Streekstra et al., 1987). Thus, it can be defined that the specific rate of ATP synthesis $\left(q_{\mathrm{ATP}}\right)$ equals $2 q_{\text {fructose }}+q_{\text {acetate }}$. The values of $q_{\text {ATP }}$ were calculated at each steady state and the plots of $q_{\mathrm{ATP}}$ against $D$ yielded a linear relationship (Table 5). Again, by using equation (1), the maximum yield referred to moles of ATP synthesized [ $Y_{\mathrm{ATP}}^{\max }, \mathrm{g}$ dry wt (mol ATP synthesized) $)^{-1}$ ] was estimated to be $15 \cdot 1$ and 20.2 in the absence and presence of bicarbonate, respectively. The $Y_{\mathrm{ATP}}^{\max }$ value of 15.1 is close to the value of 14.0 for the 
Table 5. Growth parameters of A. actinomycetemcomitans 301-b grown anaerobically in the fructose-limited chemostat culture in the absence and presence of bicarbonate

The equations are calculated by estimating the first and second regression coefficients from the data presented in Tables 1 and $2 . q$ is expressed in mmol substrate comsumed or formed ( $\mathrm{g} \mathrm{dry} \mathrm{wt})^{-1} \mathrm{~h}^{-1}$ and $Y$ in $\mathrm{g}$ dry wt (mol substrate) $)^{-1}$.

$\begin{array}{lcc}\text { Parameter } & \begin{array}{c}\text { In the absence of } \\ \text { bicarbonate }\end{array} & \begin{array}{c}\text { In the presence of } \\ \text { bicarbonate }\end{array} \\ q_{\text {fructose }} & 0.248+24.8 D(0.998)^{*} & 0.747+16.2 D(0.996)^{*} \\ Y_{\text {fructose }}^{\max } & 40.3 & 61.7 \\ q_{\text {ATP }}^{\max } & 0.985+66.4 D(0.997)^{*} & 2.047+49.4 D(0.998)^{*} \\ Y_{\text {ATP }}^{\max } & 15 \cdot 1 & 20.2 \\ \text { ATP-Efft } & 2 \cdot 7 & 3.0\end{array}$

* Correlation coefficient shown in parentheses.

† The efficiency of ATP generation is calculated as the ratio of $Y_{\text {fructose }}^{\max }$ to $Y_{\mathrm{ATP}}^{\max }$, mol ATP formed (mol fructose metabolized $)^{-1}$.

glucose-limited anaerobic chemostat culture of Aerobacter aerogenes (Klebsiella pneumoniae) possessing a similar branched fermentation pathway (Stouthamer \& Bettenhausen, 1975). The efficiency of ATP generation [ATP formed (mol fructose metabolized) ${ }^{-1}$ ] during fructose fermentation can be calculated as the ratio of $Y_{\text {fructose }}^{\max } Y_{\mathrm{ATP}}^{\max }$ and values of 2.7 and 3.0 are obtained for the cultures in the absence and presence of bicarbonate, respectively. From these parameters, it can be concluded that bicarbonate stimulates not only the efficiency of ATP formation during fructose catabolism but also the efficiency of the utilization of this energy for biosynthesis (i.e. $Y_{\mathrm{ATP}}^{\max }$ ). Further interpretation, in particular for the increase in $Y_{\mathrm{ATP}}^{\max }$, requires biochemical studies with labelled bicarbonate on the exact $\mathrm{CO}_{2}$ fixation pathway.

This work was supported in part by a grant from the Japan Foundation for Health Sciences (1988).

\section{REFERENCES}

ANDERSON, R. L. \& ORdal, E. J. (1961). $\mathrm{CO}_{2}$ dependent fermentation of glucose by Cytophaga succinicans. Journal of Bacteriology 81, 139-146.

BaumanN, P. \& BaumanN, L. (1975). Catabolism of Dfructose and D-ribose by Pseudomonas doudoroffi. I. Physiological studies and mutant analysis. Archives of Microbiology 105, 225-240.

Bergmeyer, H. U., Grassl, M. \& Walter, H.-E. (1983). Enzymes. In Methods of Enzymatic Analysis, 3rd edn, vol. 2, pp. 126-328. Edited by H. U. Bergmeyer, Weinheim: Verlag Chemie.

BEUTLER, H.-O. (1984). D-Fructose. In Methods of Enzymatic Analysis, 3rd edn, vol. 6, pp. 321-341. Edited by H. U. Bergmeyer. Weinheim: Verlag Chemie.

BRIDGeS, R. B. \& WITTENBERGeR, C. L. (1975). 6Phosphogluconate dehydrogenase from Streptococcus faecalis. Methods in Enzymology 41, 232237.

Buchanan, B. B. \& Pine, L. (1967). Path of glucose breakdown and cell yields of a facultative anaerobe, Actinomyces naeslundii. Journal of General Microbiology 46, 225-236.

VAN DiJken, J. P. \& Quayle, J. R. (1977). Fructose metabolism in four Pseudomonas species. Archives of Microbiology 114, 281-286.

DoElLE, H. W. (1975). Bacterial Metabolism. 2nd edn, New York: Academic Press.
Gracy, R. W. \& Tilley, B. E. (1975). Phosphoglucose isomerase of human erythrocytes and cardiac tissue. Methods in Enzymology 41, 392-400.

Hill, R. L. \& Bradshaw, R. A. (1969). Fumarase. Methods in Enzymology 13, 91-99.

HiRAISHI, A. (1988a). Bicarbonate-stimulated dark fermentative growth of a phototrophic purple nonsulfur bacterium. FEMS Microbiology Letters 56, 199-202.

HIRAISHI, A. (1988b). Fumarate reduction systems in members of the family Rhodospirillaceae with different quinone types. Archives of Microbiology 150, 56-60.

holdeman, L. V., Cato, E. P. \& Moore, W. E. C. (1977). Anaerobe Laboratory Manual, 4th edn, Blacksburg: Virginia Polytechnic Institute and State University.

Holm, P. (1954). The influence of carbon-dioxide on the growth of Actinobacillus actinomycetemcomitans (Bacterium actinomycetem comitans (Klinger, 1912)). Acta pathologica et microbiologica scandinavica 34, 235-248.

IINO, Y. \& HoPPS, R. M. (1984). The bone-resorbing activities in tissue culture of lipopolysaccharides from the bacteria Actinobacillus actinomycetemcomitans, Bacteroides gingivallis and Capnocytophaga ochracea isolated from human mouths. Archives of Oral Biology 29, 59-63. 
Ingraham, J. L., MaAloe, O. \& Neidhardt, F. C. (1983). Growth of the Bacterial Cell. Massachusetts: Sinauer Associates.

Jenkins, G. N. (1978). The Physiology and Biochemistry of the Mouth, 4th edn. Oxford: Blackwell Scientific Publications.

KaPke, P. A., Brown, A. T. \& Lillich, T. T. (1980). Carbon dioxide metabolism by Capnocytophaga ochraceae: identification, characterization, and regulation of a phosphoenolpyruvate carboxykinases. Infection and Immunity 27, 756-766.

Kiley, P. \& Holt, S. C. (1980). Characterization of the lipopolysaccharide from Actinobacillus actinomycetemcomitans Y4 and N27. Infection and Immunity 30, 862-873.

KITTO, G. B. (1969). Intra- and extramitochondrial malate dehydrogenases from chicken and tuna heart. Methods in Enzymology 13, 106-116.

KNAPPe, J. \& Blaschkowski, H. P. (1975). Pyruvate formate-lyase from Escherichia coli and its activation system. Methods in Enzymology 41, 508-518.

K.ORNBERG, H. L. \& REEVES, R. E. (1979). Inducible phosphoenolpyruvate-dependent hexose phosphotransferase activities in Escherichia coli. Biochemical Journal 128, 1339-1344.

LAANBROEK, H. J. (1978). Ecology and physiology of L-aspartate- and L-glutamate-fermenting bacteria. $\mathrm{PhD}$ thesis, Groningen University.

LebHERZ, H. G. \& RUTTER, W. J. (1975). The class I (Schiff base) fructose-diphosphate aldolase of Peptococcus aerogenes. Methods in Enzymology 42, 249258.

Macy, J. M., LJungdahl, L. G. \& GotTschalk, G. (1978). Pathway of succinate and propionate formation in Bacteroides fragilis. Journal of Bacteriology 134, 84-91

Mannheim, W., Stieler, W., Wolf, G. \& Zabel, R. (1978). Taxonomic significance of respiratory quinones and fumarate respiration in Actinobacillus and Pasteurella. International Journal of Systematic Bacteriology 28, 7-13.

Ohta, H., Kokeguchi, S., Fukui, K. \& Kato, K. (1986). Actinobacillus (Haemophilus) actinomycetemcomitans in periodontal disease. Microbiology and Immunology 30, 629-643.

Ohta, H., Kokeguchi, S., Fukui, K. \& Kato, K. (1987). Leukotoxic activity in Actinobacillus (Haemophilus) actinomycetemcomitans isolated from periodontal disease patients. Microbiology and Immunology 31, 313-325.

OHTA, H. \& GotTSChal, J. C. (1988). Microaerophilic growth of Wolinella recta ATCC 33238. FEMS Microbiology Ecology 53, 79-86.

OlIVE, C. \& LeVy, H. R. (1975). Glucose-6-phosphate dehydrogenase from Leuconostoc mesenteroides. Methods in Enzymology 41, 196-201.

Phillips, J. E. (1984). Genus Actinobacillus Brumpt 1910. In Bergey's Manual of Systematic Bacteriology, vol. 1, pp. 570-575. Edited by N. R. Kreig. Baltimore: Williams \& Wilkins.

PILKIS, S. J. (1975). Glucokinase of rat liver. Methods in Enzymology 42, 31-39.

PIRT, S. J. (1975). Principles of Microbe and Cell Cultivation. Oxford: Blackwell Scientific Publications.

Pulverer, G. \& Ko, H. L. (1970). Actinobacillus actinomycetem-comitans: fermentative capabilities of 140 strains. Applied Microbiology 20, 693-695.
SCHOBERT, P. \& BOWIEN, B. (1984). Unusual $\mathrm{C}_{3}$ and $\mathrm{C}_{4}$ metabolism in the chemoautotroph Alcaligenes eutrophus. Journal of Bacteriology 159, 167-172.

Schultz, J. E. \& Weaver, P. F. (1982). Fermentation and anaerobic respiration by Rhodospirillum rubrum and Rhodopseudomonas capsulata. Journal of Bacteriology 149, 181-190.

SCRUTTON, M. C. (1971). Assay of enzymes of $\mathrm{CO}_{2}$ metabolism. Methods in Microbiology 6A, 479-541.

Shenker, B. J., McArthur, W. P. \& Tsai, C.-C. (1982a). Immune suppression induced by Actinobacillus actinomycetemcomitans. I. Effects on human peripheral blood lymphocyte responses to mitogens and antigens. Journal of Immunology 128, 148-154.

Shenker, B. J., Kushner, M. E. \& Tsai, C.-C. (1982 b). Inhibition of fibroblast proliferation by Actinobacillus actinomycetemcomitans. Infection and Immunity 38, 986-992.

SLOTS, J. (1982). Salient biochemical characters of Actinobacillus actinomycetemcomitans. Archives of Microbiology 131, 60-67.

Slots, J., Reynolds, H. S. \& Genco, R. J. (1980). Actinobacillus actinomycetemcomitans in human periodontal disease: a cross-sectional microbiological investigation. Infection and Immunity 29, 1013-1020.

SPRING, T. G. \& Wold, F. (1975). Enolase from Escherichia coli. Methods in Enzymology 42, 323-329.

Stouthamer, A. H. \& Bettenhaussen, C. W. (1975). Determination of the efficiency of oxidative phosphorylation in continuous cultures of Aerobacter aerogenes. Archives of Microbiology 102, 187-192.

Streekstra, H., BuUrman, E. T., Hoitink, C. W. G., Teixeira de Mattos, M. J., Neijssel, O. M. \& TEMPEST, D. W. (1987). Fermentation shifts and metabolic reactivity during anaerobic carbon-limited growth of Klebsiella aerogenes NCTC 418 on fructose, gluconate, mannitol and pyruvate. Archives of Microbiology 148, 137-143.

Thauer, R. K., Kirchniawy, F. H. \& JungermanN, K. A. (1972). Properties and function of the pyruvate-formate-lyase reaction in clostridiae. European Journal of Biochemistry 27, 282-290.

Thjotta, T. \& SYdnes, S. (1951). Actinobacillus actinomycetemcomitans as the sole infecting agent in human being. Acta pathologica et microbiologica scandinavica 28, 27-35.

TUOMINEN, F. W. \& Bernlohr, R. W. (1975). Pyruvate kinase of Bacillus licheniformis. Methods in Enzymology 42, 157-166.

Tsai, C.-C., Shenker, B. J., DiRienzo, J. M., Malamud, D. \& Taichman, N. S. (1984). Extraction and isolation of a leukotoxin from Actinobacillus actinomycetemcomitans with polymixin B. Infection and Immunity 43, 700-705.

White, D. C., Bryant, M. P. \& Caldwell, D. R. (1962). Cytochrome-linked fermentation in Bacteroides ruminicola. Journal of Bacteriology 84, 822-828.

WITTENBERGER, C. L. (1975). D(-)-Lactate dehydrogenase from Butyribacterium rettgeri. Methods in Enzymology 41, 299-303.

Yamada, S., Takahashi-Abbe, S. \& AbBe, K. (1985). Effects of oxygen on pyruvate formate-lyase in situ and sugar metabolism of Streptococcus mutans and Streptococcus sanguis. Infection and Immunity 47, 129-134. 